\title{
Anthropological Analysis of The Sarana Dhuru Bahasa and Sarana Sabandara in The Murtabat Tujuh as The Buton Law
}

\author{
Wa Ode Sifatu ${ }^{1}$ \\ \{sifawaode@yahoo.co.id ${ }^{1}$ \} \\ ${ }^{1}$ Anthropology Department, Cultural Science Faculty, Halu Oleo University; \\ Btn Unhalu Blok W, Number 28 Kendari, Pos Code: 93232, \\ Sulawesi Tenggara, Indonesia. Telp: +62-81341762438
}

\begin{abstract}
The postmodern approach helps the writer overcome the gap between written text and discourse in contemporary society. Written manuscripts and reality and between desires and facts as a solution is to combine two elements. However, this does not mean we accept all postmodernist characteristics, as accepting the truth of discourse, because it allows us to propose aesthetic and even moral ideals which affirm the existence of certain truths and values that go beyond absolute postmodern relativism.
\end{abstract}

Keywords: Laws Buton as Literature, Reality, Truth, Morals

\section{Introduction}

Anthropological analysis is relevant to the concept of nationalism [1],[2] in the era of globalization [3] because nationalism has political effects consider the anthropological assumptions that humans can naturally classified intovariety of cultures and strictly boundaries societies [4]. In the Murtabat Tujuh as the Buton Law, Sarana Dhuru Bahasa and Sarana Sabandaraare officer in charge to overseeing the marine environment as a part of the living environment of the Buton Sultanate. Analysis of the Buton Law text is not ordinary in science. Many experts have studied about it, for example, the role of Murtabat Tujuh within the society of the Sultanate Buton Wolio [5] and Kaombo for forest, garden, and sea.

Kaombo contains set of value as the effort to manage and preserve the natural environment in the Sultanate of Buton [5]. Now, formal leadership ignores management and supervision of preservation of the Kambo forest area, but remains the responsibility to Parabhela and his custom institution in the former Buton Sultanate [6]. Gender role in the Kaombo traditional institutions are still effective and has high responsive to its issue [7],[8], The obedience of Burangasi community towards the rules of Kaombo gardens and the sea, and have developed into capital sea Kaombo and native sea Kaombo towards marine conservation [9],[10]. Legal values in the Buton Act [11]. Sufism element study in the text of Buton Law [12]. Anthropological analysis is not yet available on the Sarana Dhuru Bahasa and Sarana Sabandara for the development of local wisdom to support various rules of marine management [13],[14],[10]. The theory use for reading data research is form of capital theory [15] with ethnography methods. Capital as the capacity of individuals in the postmodern era has operated in the Buton Sultanate before the arrival of the postmodern era. 


\section{Research Methods}

This study uses ethnographic methods. In addition to Bourdieu's ethnographic method [16], researcher also read [17],[16],[18],[19], as a conclusion, this research took a number of steps as follows.

\subsection{Location of Research}

The location of this study was purposely determined, namely the City of Baubau as the center of the Buton Sultanate, Simalui Jaya village as the oldest Parabela region, so it was considered to have more complete data and information about the Laws on Buton.

\subsection{Data Sources}

The research data consists of two sources, namely secondary data sources and primary data sources. Secondary data sources consist of books, journals, and manuscripts of Buton laws. While the primary data comes from the results of in-depth interviews and observations.

\subsection{Data Collection Procedure}

Data is collected and integrated in the analysis process, and presented in a way that supports the main themes of the research focus, so that it is a separate construction as a product of interaction between informants and researchers. Data collection techniques used as follows.

\subsubsection{In-depth Interviews}

In-depth interviews were addressed to key informants i.e. the Secretary of the Buton Sultanate, La Ode Zaali and Sultan Buton La Ode Muh. Izat Manarfah, Parabhela, village head, Imam, customary head, cultural observer, lecturer, administrator of non-governmental organizations (NGOs). Information is obtained to get information about him, his business activities, family life, or his outlook on life. The informants also guided to explain things outside of himself, such as the condition of society, production relations in working groups and social relations in society, especially in emphasizing social institutions both of which are cultural or structural /organizational.

\subsubsection{Observation}

Observations are carried out in two ways, namely, ordinary observation and participating observation. Through ordinary observation data is obtained about community activities regarding the Sarana Dhuru Bahasa and the Sarana Sabandara. While participating observation is To obtain data that requires the involvement of researchers, such as the behavior and activities of informants, local institutions and matters relating to behavior, and their meanings.

\subsubsection{Study Documents}

The document study was carried out by reviewing a number of written sources both related to the subject matter and location to obtain primary and secondary data. 


\subsection{Data Validation}

This context finds four criteria for evaluating data, described as follows.

\subsubsection{Data Credibility}

Validation of internal data is done by matching the findings during interviews with informants with: [20] the results of continuous observations of important facts, checks, and explanations of theories for the interpretation of symptoms that occur during the study, [21] meet all informants, community, and scientists who know Murtabat Tujuh, so that the evidence be authentic to the assumptions that emerged during the study, [7] the researcher confirmed the informant on data, categories, interpretations and conclusions, then tested it together with the informants who involved in the research from the beginning.

\subsubsection{Transferability}

Informations in this research gained In detail and in depth about the background of the socio-cultural life of the people of Buton, through analysis and availability of adequate information so that it reflects the characteristics of the community towards Murtabat Tujuh as the Buton law.

\subsubsection{Dependency}

The researcher involved the auditor to examine the existence of the topics studied at the chosen location and also examine the data and information collected by the researcher while maintaining the consistency of the research results with the conclusions formulated.

\subsubsection{Confirmation}

The researcher also conducts self reflection and critical thinking by outlining the basic assumptions of cultural values in relation to the marine environment. This activity aims to achieve trust in the results of research. This data confirmation activity is carried out from the beginning of data retrieval until the writing process takes place.

\subsection{Data Analysis Techniques}

The data of this study were analyzed descriptively qualitative through interpretation and understanding. Field notes are coded according to the problem. Coding data based on the results of criticism made, the appropriate data is separated by certain codes. The data obtained is analyzed comparatively through three stages, [20] The process of crude data reduction from field notes, selected data that is relevant to the focus of the study; [21] Data is presented in the form of narrative texts; [7] Drawing conclusions gradually until general conclusions are obtained using inductive methods. That is, this study does not test hypotheses, but instead prepares abstractions based on the parts that have been collected and grouped by making a comprehensive and holistic analysis of all elements which are the main problems in the study. 


\section{Results And Discussion}

\subsection{Territory of the Buton Sultanate}

Past forms of government in the Buton Sultanate [11],[13],[22],[23] have experienced a number of shifts, from the royal government system to the sultanate government system and later became the part of Republic of Indonesia in 1960, and became part of the Indonesian program as Axis World Maritim [24]. The shifts in the system of governance in the Sultanate of Buton may produce dynamics in socio-cultural life. The Buton Sultanate in the past was located in parts of the archipelago and in the Southeast coast of the island of Sulawesi as the present Southeast Sulawesi Province (Sultra). For more details, see the following map.
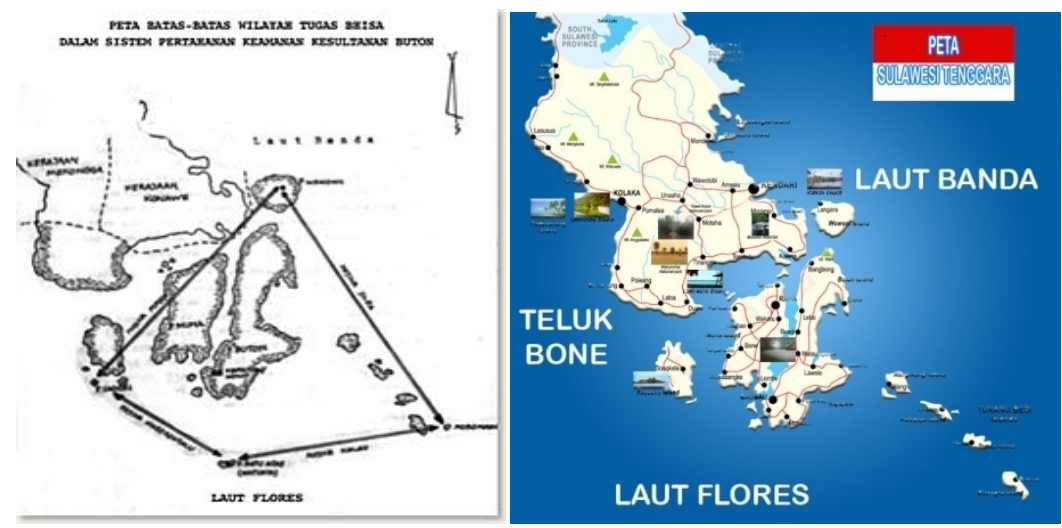

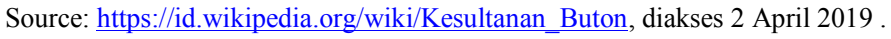

The map above shows that the Buton Sultanate appears to be wider than the current Southeast Sulawesi Province. The former Buton Sultanate has a number of local relics and wisdom in various aspects of life, including the marine environment. Various results of research on the benefits and functions of local wisdom in the development of coastal and marine communities.

\subsection{Background The Formation of the Murtabat Tujuh as The Buton Law}

The formation of the Law on Buton [5],[12],[22],[23] in the era of leadership of Dayanu Iksanuddin was motivated by a number of factors as follows.

1) State security conditions are not conducive, community members often act outside the humanitarian corridor. Humanity that distinguishes humans from animals is in addition to physical elements, humans are also equipped with elements of creativity, elements of taste, and elements of intention. Humans are created by God in a best and most beauty form. Its humanity must be maintained. Otherwise, humans can become more despicable than animals. The space to maintain form of humanitarian degree is a family, with the smallest unit called a household. Through household as a place to develop the character of each member, as said by informant La Ode Manarfa: "children are still under the guidance and responsibility of their parents. The way a family treats its children will have an impact on the development of the children's behavior ". 
2) The absence of a written constitution that determines the authority of the state administration as a guideline for its management.

3) The occurrence of a long drought in the era of the third Sultan, La Sangaji resulting in famine in the people of Buton.

Sultan Dayanu Ikhsanuddin thought wisely to make a law to be a guideline for his people behavior in the government of the Buton Sultanate. He was assisted by Syarif Muhammad, who create guideline based on the Al Qur'an and Al Hadist. Since the establishment of the Buton Law, the behavior of the Buton community has been controlled, state security is conducive without the arbitrariness of the people or the government.

\subsection{Position of Sarana Dhuru Bahasa and Sarana Sabandara in the Buton Law and Its Defense in the Contemporary Society}

The position of the Sarana Dhuru Bahasa and Sarana Sabandara in the Buton Law can be seen through the composition of officials or governmental authorities of the Buton Sultanate, in general, the following are.

1) Syara Ogena Officials/Authorities: (a) Sultan, (b) Sapati; (c) Kenepulu; (d). Kapitaraja / Kapitalau; (e) Sorawolio Lakina.

2) Majelis Syara (has a supervisory function): (a) Bonto Ogena; (b) Bonto Sio limbona, (c) Bonto Inunca (palace staff); (d) Bonto Lencina Kanjawari; (e) Bonto and Bobato.

3) Special staff of the sultanate: (a) Sarana Sabandara; (b) Sarana Dhuru Bahasa; (c) Talombo; (d) Gampikaro; (e) Panggalasa; (f) Wantina Gampikaro; (g) Kenipu; (h) Belobaruga; (i) Tamburu Limanguna; (j) Kompanyia Isyara; (k) Tamburu Pataanguna; (1) Matana Sorumba.

4) Servant of Syara Kidina/Religious Education: (a) Lakina Agama, (b) Imamu, (c) Khatibi, (d). Moji, (e) Mokimu, (f) Bhisa Patamiana.

Information obtained on the ground that Sarana Sabandara and Sarana Dhuru Bahasa are special staff of the Sultan of Buton whose have duty at sea and at the port. Every trader who travels on land must be accompanied by Sarana Dhuru Bahasa. Usually, traders come from around the land of Bugis. Sarana Dhuru Bahasa is a translator. All traders from outside Buton must be accompanied by them eventhough they are good at speaking Wolio language. Sarana Dhuru Bahasa is not only a translator, but also the taxes collector. Sarana Sabandara is the Head of the Port in the Buton Sultanate. Sarana Dhuru Bahasa is a tax collector and also in charge to accompanying the Sultan of Buton to travel to the coast or cross to small islands outside Buton Island.

Sarana Dhuru Bahasa uses its own rules.Buton harbor unavoidable by passers from Bugis to Ternate or vice versa, the sailor must stop by at the harbour to refuel the ship or to bought stores for the voyage, for the security to face the Banda Sea. When the merchants who were at sea and seemed to be arriving at the port of the Buton Sultanate, the Sarana Dhuru Bahasa rushed to the ship and prepared various questions, including ask about whether there were souvenirs for the Sultan? The answers to such questions are expected in the two categories of souvenirs, namely [20] the category of souvenirs for the Sultan and [21] the category of souvenirs for Sarana Sabandara. If there is only one category, it cannot be divided into two. The strategic Sarana Dhuru Bahasa must ask again, are there others souvenirs? If not, the Sarana Dhru Bahasa returns it to the owner of the ship until there are two categories by it. If not, then the ship is not permitted to enter the port of the Buton Sultanate. Ship owners are usually from Tobelo, Ternate, Tobungku, and Luwu. 
The geographical location of the Buton Sultanate deliver capital (Bourdieu, 1983), for the Sultanate to the Kingdom of Tobelo, Sultanate of Ternate, Kingdom of Tobungku, and Kingdom of Luwuk, and executed by Sarana Dhuru Bahasa. In the case of a marine fish thief in the area of the Buton Sultanate, Sarana Dhuru Bahasa ran to report and ask for help to the palace about the incident. On his way to go and return to the palace, the Sarana Dhuru Bahasa can take a ride from the community and the community is not allowed to refuse because it is used to be a ride and accelerate his journey to the palace and to the thief ship in the sea. On the ship, the Sarana Dhuru Bahasa captures the ship and calculates the price, starting from the price of the ship to all its contents. The results of these calculations are reported to the king from the intended ship. The king as the origin of the fishers in the Buton Sea was obliged to come to the palace of the Sultan of Buton to pay sum of money based on the results of calculations from the Sarana Dhuru Bahasa. The king as the origin of the fish chasers in the Buton Sea must have felt embarrassed if he had to deal with the Sultan of Buton as a result of dishonorable behavior from members of his community. Therefore, each king will guard his citizens so that they do not go wrong, and also deliver capital for all kingdoms and sultanates around Buton. Capital rules between kings or between sultans can generate conflict and that is why the Sultan of Buton had to form a coalition with the Dutch to confront the king or the sultan who complained about the rules.

Beside as a translator and trade manager, Sarana Dhuru Bahasa also accompanied the Sultan of Buton at a certain time, so that, he also had capital to the Sultan of Buton. In his daily activity, The Sarana Dhuru Bahasa must submit to Sarana Sabandara as the head of the port, so that Sarana Sabandara in this case has capital to the Sarana Dhuru Bahasa. Capital was not practiced by the Buton community now because it had followed the principles of the government system in the 1945 Constitution since 1960, precisely at the time the Buton Sultanate began to join the Negara Kesatuan Republik Indoneia (NKRI). In terms of rights, Indonesian human and community rights are guaranteed constitutionally in the UUD (1945) Constitution) Article 33. Their manifestations are contained in [25],[26],[27]. However [28] in his research in Central Sulawesi, Lore Lindu found that the formulation of development program planners so far in Indonesia was not in line with the target needs of development projects, both those formulated by the Indonesian government or NGOs. Question "why does coastal development continue to have a negative impact? [1], the preparation of Regional Regulations for the Zoning Plan for Coastal Areas and Small Islands (RZWP3K) in all provinces in Indonesia has also not been pro-people [29]. If the above conditions continues to occur, it can undermine the attitude of nationalism and it will be difficult to achieve the goals of Pancasila and the UUD 1945 Constitution. The attitude of nationalism is closely related to political, economic, social and intellectual attitudes, [1],[2]. Preservation of cultural values and enriching the understanding of the traditional social institutions that live in the community are recognized in the legal system and rules for the management of coastal areas [27]. This is a demand of Law No. 5 of 2017 concerning Promoting the culture of the Republic of Indonesia. Likewise, the legal assessment of protection of the community [26],[27],[10],[3].

\section{Conclusion}

This research has found that capital as an individual capacity known as the model of human power in the postmodern era, which began in the early $1980 \mathrm{~s}$, has prevailed in the Buton Sultanate in the modern era even though the pattern of human thought is still relatively ancient. The local vulnerability in environmental management that is still maintained is the local wisdom of Kaombo, proven to be still effective in human development today. However, 
Kaombo's local wisdom has not yet received support from formal local government so the potential for being forgotten is also quite large.

The forgetfulness of the Sarana Dhuru Bahasa, Sarana Sabandara, and Kaombo because of the unavailability support from the local formal government can accelerate the process of derivation of the nationalismattitude in the former Buton Sultanate. It is better if the implementation of the regional autonomy government system provide opportunities for the local formal government to explore and socialize back to the community so that it can be a tool to strengthen the sense of nationalism in the local community.

Acknowledgments. We would like to thank Research's directorate and Society Devotion, Research's Ministry, Technology, and Higher Education Republic of Indonesia for motivating and support through this rsearch. Our Halu Oleo University, notably Observational Institute and Devotion to Society. All our colleagues in Halu oleo University, all societies at Kota Baubau, Kampung Simalui Jay, specially La Ode Zaali, La Ode Muh. Izat Manarfah, Parabhela, Kepala Desa, Imam, Kepala adat, La Niampe, have been instrumental in the preparation, research in Kota Baubau and Simulai Jaya. This work is dedicated to La Ode Muh. Izat Manarfah as the Buton Sultane's regent of Buton and his indelible work supporting all stakeholders.

\section{References}

[1] Gellner, Ernest. Nations and Nationalism. Ithaca Ny: Cornell University Press, 1983.

[2] Sneyder, Louis. The new nationalism, Ithaca, N.Y., Cornell University Press, 1968.

[3] Appadurai, Arjun. Disjuncture and Difference in the Global Cultural Economy. Theory Culture Society. Sage Publication. Vol 7, p. 295-310, 1990.

[4] Saifuddin, Achmad Fedyani. Catatan Refleksi Antropologi Sosial Budaya. Jakarta: Institut Antropologi Indonesia, 2011.

[5] Nalefo, La. The Role of Martabat Tujuh within the Society of the Sultanate Buton Wol i o. Asian Culture and History; Vol. 10, No. 1; p.6-18, 2018.

[6] Husain, M.N. Kepemimpinan Parabela Terhadap Sikap Masyarakat Dalam Menjaga Kelestarian Kawasan Hutan Kaombo Di Kabupaten Buton. Disertasi.Sekolah Pasca Sarjana, Universitas Gadjah Mada, Yogyakarta. 355 hal, 2014.

[7] Anggraini D., dan Muhammad Najib Husain. A Study Of Buton Society Local Wisdom In Conserving The Gender Based Forest. Advancesin Social Sciences Research Journal (ASSRJ, Vol. 4 Number 19, p.12-18, 2017. http://dx.doi.org/10.14738/assrj.419.3631.

[8] Anggraini D., dan La Ode Muh. Umran. A Study Of The Marine Resource Management Strategies Of The Indigenous Communities With in Wasuemba Buton District. Academic Research International Vol. 8 (4) December, 2017. Vol. Number p. 144 153 .

[9] Wa Ode Sifatu. Kepatuhan Masyarakat Terhadap Kaombo: Studi pada Masyarakat Burangasi di Kabupaten Buton, Kendari: Universitas Halu Oleo, 2018.

[10] Wa Ode Sifatu, and Bahtiar. Synchronization of Local Knowledge With Formal Regulations Supporting Natural Resource Conservation in Bajo Communities in Muna Barat District. Paper Presentation on "ADRI International Conference on Sustainable Coastal-Community Development”. Kolaka, USN, Monday, 3-4 December, 2018.

[11] Dick, H. W. Perahu Shipping in Eastern Indonesia, Part I, Buletin of Indonesian Economic Studies II: 2 (pp. 69-107), 1975. 
[12] Niampe, La. Unsur tasawuf dalam naskah Undang-Uundang Buton. Jurnal Literasi, volume. 1, no. 1, pp. 43 - 58, 2011.

[13] Reston, VA. Vermeji, J. The Formation of the Butoness Sultanate: Dutch Political Involvement in the Creation and Maintanance of Butonese Sultanate MA. Thesis Submitted at Australian National University. 17 www.ccsenet.org/ach Asian Culture and History Vol. 10, No. 1; 2018, 2000.

[14] Suhana. Belajar dari Suku Bajau dan Kearifan Lokal Desa Autubun, 2008.

[15] Bourdieu, Pierre. Form of Capital. Originally Published as "Ökonomisches Kapital, kulturelles Kapital, soziales Kapital." in Soziale Ungleichheiten (Soziale Welt, Sonderheft 2), edited by Reinhard Kreckel. Goettingen: Otto Schartz \& Co. pp. 183-98. Translated by Richard Nice, 1983.

[16] Denzin, Norman K. And Yvonna S. Lincoln (eds). The Sage Handbook of Qualitative Research. London, New Delhi: Sage Publication, 2005.

[17] Bogdan, Robert C. Participant Observation in Organizational Setting, Syracuse, N.Y. Syracuse University Press, 1972.

[18] Emerson, Robert M. Fretz Rachel I. dan Shaw L. Linda. Writing an Ethnography dalam Writing an Ethnography Fieldnotes. Chicago: Universitaty of Chicago Press. pp, 107244, 1995.

[19] Fetterman, David M. Ethnography. Step by Step. California: Sage Publication, 1989.

[20] Ambari, M. Kenapa Pembangunan Pesisir Terus Berdampak Negatif?” dalam Mongabay Jakarta 18 Januari, 2019. https://www.mongabay.co.id/2019/01/18/ kenapapembangunan-pesisir-terus-berdampak-negatif/ diakses 10-April 2019.

[21] Anggraeni et al. Analisis Zonasi Sembilan Kawasan Konservasi di Sulawesi Tenggara. Coastal and Ocean Journal (COJ) 2017 Pusat Kajian Sumberdaya Pesisir dan Lautan - IPB (PKSPL-IPB), 2017.

[22] Zahari, A. M. Darul Butuni. Sejarah dan Adatnya. Unpublish manuscripts, 1980.

[23] Zuhdi, S. Labu Rope Labu Wana. Sejarah Buton Abad XVII-XVIII. Disertasi Universitas Indonesia (in Indonesia), 1999.

[24] Widodo, Joko (2015) Materi Pidato di KTT Asia Timur, di Nay Pyi Taw, Myanmar, Kamis (13/11/2015). http://www.presidenri.go.id/berita-aktual/indonesia-sebagai-poros$\begin{array}{lllll}\text { maritim-dunia.html, } & \text { diakses } & 14 & \text { Januari } & 2018 .\end{array}$ https://id.wikipedia.org/wiki/Kesultanan_Buton diakses tanggal 25 Maret 2019.

[25] UU Republik Indonesia Nomor 32 Tahü 2009 Tentang Perlindungan dan Pengelolaan Lingkungan Hidup.

[26] Undang-Undang Republik Indonesia Nomor 27 Tahun 2007 Tentang Pengelolaan Wilayah Pesisir Dan Pulau-Pulau Kecil.

[27] UU Republik Indonesia Nomor 5 Tahun 2017 Tentang Pemajuan Kebudayaan Republik Indonesia.

[28] Li, Tania Murray. The Will to Improve: Governmentality, Development, and the Practice of Politics. Durham, NC: Duke University Press, 2007.

[29] Hadiwinata, Marthin. Pernyataan Ketua Harian DPP Kesatuan Nelayan Tradisional Indonesia (KNTI) dalam Mongabay Jakarta 18 Januari, 2019. https://www.mongabay.co.id/2019/01/18/ kenapa-pembangunan-pesisir- terusberdampak-negatif/ diakses 10-April 2019. 